\title{
9 \\ CHALLENGING TRADITIONAL ISLAMIC AUTHORITY: The Impact of Social Media in Indonesia
}

\author{
Nadirsyah Hosen \\ Faculty of Law, Monash University, Australia
}

\begin{abstract}
Islamic teaching is, in fact, the product of a very slow and gradual process of interpretation of the Qur'an and the collection, verification and interpretation of the Hadith during the first three centuries of Islam (the seventh to the ninth centuries AD). This process took place amongst scholars and jurist who developed their own methodology for classification of sources, derivation of specific rules from general principles, and so forth. The traditionalist approach of learning Arabic, for instance, take years to complete and memorising the Arabic grammar takes a long time. Traditionalist Islamic institutions such as pesantren and madrasah produce Kiai, or Muslim clergy and scholars that inevitably create an elite group of scholars. They become the authority who determine the correct interpretation of the Holy books. However, in the era of the social media, such traditional authority has been challenged. Anyone could become a scholar of Islam and to criticise the Kiai harshly. My presentation will critically evaluate this new situation faced by the Indonesian Muslim scholars and to discuss the roots of the problems.
\end{abstract}

Keywords: Traditionalism, Islamic authority, social media, Indonesia

\begin{abstract}
Abstrak: Ajaran Islam, pada kenyataannya, adalah produk dari proses penafsiran alQur'an yang sangat lambat dan bertahap dan pengumpulan, verifikasi dan interpretasi Hadis selama tiga abad pertama Islam (abad ketujuh hingga kesembilan M). Proses ini terjadi di antara para sarjana dan ahli hukum yang mengembangkan metodologi mereka sendiri untuk klasifikasi sumber, derivasi aturan khusus dari prinsip-prinsip umum, dan sebagainya. Pendekatan tradisionalis untuk belajar bahasa Arab, misalnya, membutuhkan waktu bertahun-tahun untuk menyelesaikan dan menghafal tata bahasa Arab membutuhkan waktu yang lama. Institusi Islam tradisional seperti pesantren dan madrasah menghasilkan Kiai, atau ulama dan cendekiawan Muslim yang mau tidak mau menciptakan kelompok ulama elit. Mereka menjadi otoritas yang menentukan interpretasi yang benar dari kitab-kitab suci. Namun, di era media sosial, otoritas tradisional seperti itu telah ditentang. Siapa pun bisa menjadi sarjana Islam dan mengkritik Kiai dengan keras. Presentasi saya akan mengevaluasi secara kritis situasi baru yang dihadapi oleh para cendekiawan Muslim Indonesia dan untuk membahas akar masalah.
\end{abstract}

Kata Kunci: Tradisionalisme, otoritas Islam, media sosial, Indonesia 


\section{A. Introduction}

One can always find scriptural verses to legitimise both the slaughter and the acceptance of the Other. The same Qur'an which states 'slay the idolaters wherever you find them' (9:5) also states 'Let there be no compulsion in religion' (2:256). Likewise, the Qur'an states: "And had your Lord willed, those on earth would have believed - all of them entirely. Then, [Oh Muhammad], would you compel the people in order that they become believers?" (10:99), the Prophet Muhammad was reported to say in a Hadith: "I have been commanded to fight the people until they say there is no God but Allah".

Islamic radicalism will recite and quote the appropriate verses and the statements of the Prophet to justify their ideology. This literal meaning has been preached on television, radio, and religious gatherings, using the translation of the Qur'an and the Hadith, without any understanding of the context of those Holy texts or examination of key Qur'anic passages, along with the socio-political context of the prophet's life, and comparison of pre-modern and modern interpretations, to show the evolving nature of interpretation. The slogan 'back to the Qur'an and the Hadith' has been reduced to 'return to the literal translation of the two primary sources'. I would argue that such a minimalist approach is clearly at odds with the history of interpretations over the first 300 years of Islam.

There is the view that Islamic teaching is immutable, because the authoritarian, divine and absolute concept of revelation in Islam does not allow change in Islamic teachings and institutions. The Qur'an and the Hadith are considered immutable, regardless of history, time, culture, and location. Muslims may change, but Islam will not. This means that, by these lights, the rulings pronounced in the Shari'a are static, final, eternal, absolute and unalterable. In other words, its idealistic nature, its religious nature, its rigidity and its casuistic nature lead to the immutability of Islamic teachings. ${ }^{201}$ For Textualists, it is the Qur'an which should guide Muslims, rather than any so-called modern 'needs'. They consider the meaning of the Qur'an to be fixed and universal in its application. ${ }^{202}$

However, the view above is only one side of the same coin. Islamic teaching is, in fact, the product of a very slow and gradual process of interpretation of the Qur'an and the collection, verification and interpretation of the Hadith during the first three centuries of Islam (the seventh to the ninth centuries AD). This process took place amongst scholars and jurist who developed their own methodology for classification of sources, derivation of specific rules from general principles, and so forth. ${ }^{203}$ The Qur'an and the Hadith must involve human interpretation. The Qur'an and the Sunna cannot be understood, nor have any influence on human behaviour, except through the efforts of (fallible) human beings.

\section{B. Brief Overview of Interpretation in Islam}

Even though Islam is based on the revelations of God, it cannot possibly be drawn up except through human understanding, which means both the inevitability of differences of opinion and the possibility of error, whether amongst scholars or the community in general. Whilst the Qur'an contains a variety of elements, such as stories, moral injunctions, and general, as well as specific, legal principles, it should be noted that the Qur'an prescribes only those details which are essential. It thus leaves considerable room for development, and safeguards against restrictive rigidity. The Contextualists argue for a high degree of freedom for the modern

${ }^{201}$ See the discussion in Muhammad Khalid Masud, Shatibi's Philosophy of Islamic Law (Pakistan: Islamic Research Institute, 1995), 17.

202 Abdullah Saeed, Interpreting the Qur'an: Towards a Contemporary Approach (New York: Routledge, 2006), 3.

${ }^{203}$ Robert Gleave, Islam and Literalism: Literal Meaning and Interpretation in Islamic Legal Theory (Edinburgh: Edinburgh University Press, 2012). 
Muslim scholar, in determining what is mutable (changeable) and what immutable (unchangeable), in the area of socio-ethico-legal content.204

It is not only the disorderly and complex nature of the document which makes the Qur'an difficult to interpret. One of the fundamental reasons for differences of opinion over the Quran lies in the ambiguous language used in some verses. The fact that these words are given debatable meanings is a sign from God that they were meant to be ambiguous and subject to different opinions. A ruling in the Qur'an may be conveyed in a text which is either clear, or which is open to different interpretations. A definitive text is one which is clear and specific; it has only one meaning and admits of no other interpretations. It is known as Qat'i. The rulings of the Qur'an on the essentials of the faith, such as ritual, are all Qat' $i$ - their validity may not be disputed by anyone; every Muslim must exercise them, and they are not open to ijtihad (independent legal reasoning). Thus, there is no disagreement on Qat'i cases. The second type of ruling is that which is considered speculative (Zanni). A single word in a Qur'anic text may have several different meanings, which may have different legal consequences. ${ }^{205}$

Perhaps more difficult is the lack of guidance from the Prophet regarding how the Qur'an should be interpreted. Famously, the Prophet advocated both literal and contextual interpretations of the text. In one story, the Prophet directed a group of his companions, 'Do not perform the mid-afternoon prayer until you get to Banu Qurayzah.' When the time came, some took the Prophet's words literally and would not pray until they reached Banu Qurayzah. The others, however, took the Prophet's words more liberally, believing he simply meant for them to hurry to Banu Qurayzah and get there before mid-afternoon. When this story was retold to the Prophet, he did not disapprove of either group. 206

Taha Jabir al-Alwani explains the significance of this story:

It is clear from this incident that the Companions of the Prophet had split into two groups over the interpretation of the Prophet's instructions - one group adopting the literal or explicit meaning of the injunction ('ibaarat al nass) while the other group derived a meaning from the injunction which they considered suitable for that situation. The fact that the Prophet approved of both groups showed that each position was legally just as valid as the other. Thus, a Muslim who is faced with a particular injunction or text (nass) can either adopt the literal or manifest (zaahir) meaning of the text or he may derive interpretations which are appropriate to the text by using his reason. ${ }^{207}$

The clash of the literal and the interpretive is a huge source of debate between Islamic scholars and jurists, and is arguably the main reason there are multiple schools of thought within Islam. Clearly, the Qur'an cannot practically be the only source of Islam. This leads us to the second source. The Hadith contain reports of anything Muhammad said or did or approved of during his life as the Prophet. As they are believed to contain the words and stories of the Prophet, and the Prophet is believed to have spoken to God, the Hadith are considered incredibly important to Muslims and provide guidance on life, law and the interpretation of the Qur'an. The Hadith are particularly significant as they heavily influenced and shaped early commentaries on the Qur'an and formed the basis of Shari'a. The Hadith form the most important tool for understanding the Qur'an. The Prophet is 'considered the first and best interpreter of the Qur'an,

204 Saeed, Interpreting the Qur'an, 2, 3.

205 Badr al-Din al-Zarkashi, Bahr al-Muhith fi Usul al-Fiqh, Vol. 1 (Beirut: Dar al-Kutub al-Ilmiyyah, 2007), 140; see also M. Hashim Kamali, Principles of Islamic Jurisprudence (Cambridge: Cambridge Islamic Texts Society, 1991), 19-20.

206 See Taha Jabir al-Alwani, The Ethics of Disagreement in Islam (Herndon, Virginia: The International Institute of Islamic Thought, 2011), 20-21.

207 Ibid. 
and thus any record of his thoughts may provide clues as to the meaning of Qur'anic texts.'208 Essentially, where the Qur'an provides a broad framework for the Muslim way of life, the Hadith provide the details. For example, the Qur'an instructs Muslims to pray, but the Prophet teaches how and when to pray within the Hadith.

However, the existence of the Hadith does not necessarily make interpretation of law straightforward or easy for Muslims. Brown explains further:

Grounded in the prosaic moments of everyday life, and many thousands of times more numerous than Qur'anic verses, Hadith reports were even more entwined in historical context. Muslim scholars labored endlessly to determine if specific Hadith addressed specific situations and persons, or if they constituted general commandments. 209

There is much debate about the authority of Hadith in determining law. There have also been difficulties in authenticating and verifying Hadith, as records of the Prophet's life were not documented until well after his death. Verifying Hadith involved the complicated task of sifting through fabricated stories and corroborating chains of narration. It ultimately gave rise to a distinct field of scholarship dedicated to the verification and preservation of Hadith.210 This was, of course, a perilously difficult process, and not all Muslims have the required knowledge to verify the chain of authority in four different categories: sahih (sound), hasan (good), da'if (weak) and maudu' (fabricated). ${ }^{211}$ Any Hadith found to have been passed down by a 'defective or interrupted chain of transmitters, or by transmitters known to be untrustworthy, was held to lack any legal effect.212' Transmitters were judged on their ability to transmit a Hadith in full and verbatim, on their age, as maturity indicated a superior ability retain reliable information, on their relationship to the Prophet, whether close or distant, and whether there was a strong thematic corroboration between their narration and the Qur'an. ${ }^{213}$

This leads to the third source. Ijtihad in Islamic law can be defined simply as 'interpretation.' The main difference between ijtihad and both the Qur'an and the Sunna is that ijtihad is a continuous process of development whereas the Qur'an and the Sunna are fixed sources of authority, and were not altered or added to after the death of the Prophet. ${ }^{214}$ The rule of ijtihad originated at the time the Prophet, when he sent Mua'z ibn Jabbal to Yemen as a judge. They engaged in the following dialogue before the latter's departure:

'What will you do if a matter is referred to you for judgement?' Mua'z said, 'I will judge according to the Book of Allah.' The Prophet asked, 'What if you find no solution in the Book of Allah?' Mua'z said, 'Then I will judge by the Sunnah of the Prophet.' The Prophet asked: 'And what if you do not find it in the Sunnah of the Prophet?' Mua'z said: 'Then I will make ijtihad to formulate my own judgement.' The Prophet

\footnotetext{
208 Asifa Quraishi, "Interpreting the Qur'an and the Constitution: Similarities in the Use of Text, Tradition, and Reason in Islamic and American Jurisprudence", Cardozo Law Review, 28 (2006): 67, 85.

209 Jonathan AC Brown, Misquoting Muhammad: The Challenge and Choices of Interpreting the Prophet's Legacy (London: Oneword Publications, 2014), 98.

210 Ibid., 69.

211 See the explanation of these terms in M. Hashim Kamali, A Textbook of Hadith Studies (Markfield, UK: The Islamic Foundation, 2009), 139-154.

212 Wael B. Hallaq, An Introduction to Islamic Law (Cambridge University Press, 2009), 17.

213 Ibid., 18.

214 Mohammad Hashim Kamali, Principles of Islamic Jurisprudence (Cambridge: The Islamic Text Society, 1991), 366.
} 
patted Mua'z's chest and said: 'Praise be to Allah, Who has guided the messenger of His prophet to that which pleases him and His Messenger.'215

However, it should be stressed that the concept and the meaning of ijtihad, as used in the conversation above, is different to ijtihad in its current context. Throughout history the meaning of ijtihad has altered according to place and circumstance. During the times of the Prophet and his Companions, it should be noted that ijtihad was still very much an abstract, rather than a generally applied or apprehended concept.

In the period of 'aimmat al-madzahib (the leaders of school of thoughts), Abu Hanifah (d. 150 A.H./767 C.E.), the founder of the Hanafi school, was reported as having said:

I follow the book of Allah, and if I find no solution there, I follow the Sunnah of the prophet, peace be upon him, If I find no solution in either the Qur'an or the Sunnah, I follow whichever of the pronouncements of the companions of the Prophet I prefer, and leave whichever I wish. If there is a pronouncement on a particular matter by any of the companions, I would not adopt any other opinion made by any other scholar. But if I found a solution only in the opinions of Ibrahim, al-Syu'bi, Ibn Sirrin, al-Hasan, or Sa'id ibn al- Musayyab, I would make ijtihad, just as they did.216

Abu Hanifah here not only describes his method of, and the procedure to be adopted in the case of, ijtihad, but also defines what the procedure of ijtihad was. It is instructive to explore the meaning of ijtihad in the Muwatta' of Imam Malik (d. 179 A.H./795 C.E.), since this book is usually considered to be amongst the earliest of Islamic juristic works. ${ }^{217}$ Ahmad Hasan explained that Malik used the term ijtihad generally, for cases where he could find no definite answer from the Prophet, or in commonly agreed practice and, therefore, left the matter to the discretion of the Imam to decide. ${ }^{218}$

In modern times, ijtihad can be conducted in one of at least three ways: ijtihad bayani, ijtihad qiyasi and ijtihad istislahi. ${ }^{219}$ The first (ijtihad bayani) may be applied to cases which are explicitly mentioned in the Qur'an or Hadith but need further explanation. The second (ijtihad qiyasi) may be applied to cases which are not mentioned in these two sources, but which are similar to cases mentioned in either of them. The third method, ijtihad istislahi, may be applied to those cases which are not regulated by the Qur'an nor Hadith, and cannot be solved by using analogical reasoning. In this case, maslahah (utilities) is considered to be the basis for legal decisions.

\section{Reading the Qur'an and the Hadith through Translation in Social Media}

Most Indonesian learn how to read the Qur'an in Arabic, but only few of them can understand the meaning. That's because the focus mostly on performing ritual in Arabic. A few who study in pesantren or madrasah learn Arabic grammar, and can not only read, and understand what they read in, the Qur'an, but can also read Arabic classic books (known as kitab kuning) - which form rich sources of Islamic literature.

The traditionalist approach of learning Arabic take years to complete and memorising the Arabic grammar takes a long time. Both pesantren and madrasah produce Kiai, or Muslim

${ }^{215}$ Abu Dawud Sulaiman, Sunan Abi Dawud (Beirut: al-Maktabah al-'Ashriyah, 1952). hadith number [HN]: 3, 119; Abu Muhammad al-Darimi, Sunan al-Darimi (Beirut: Dar al-Kitab al-'Arabi, 1997), HN 168; AlTirmizi, Sunan al-Tirmidhi (Beirut: Dar al-Fikr, 1963).

${ }_{216}$ Muhammad Salam Madkur, Manahij al-Ijtihad fi al-Islam (Kuwait: Matba'ah al-Ashriyah, 1977), 57-58.

217 See the analysis on al-Muwatta' in Norman Calder, Studies in Early Muslim Jurisprudence (Oxford: Clarendon Press, 1993), 20-38.

${ }^{218}$ Ahmad Hasan, The Early Development of Islamic Jurisprudence (Islamabad: Islamic Research Institute, 1970), 116.

${ }^{219}$ Muhammad Ma'ruf al-Dawalibi uses these classifications in his book al-Madkhal ila 'Ilm al-Usul al- Fiqh (Damascus: Matba'ah Jami'ah Damshiq, 1959), 389. 
clergy and scholars. This inevitably creates an elite group of scholars. They become the authority who determine the correct interpretation of the Holy books. This is what the Wahabi movement tried to reject. Anyone, according to Wahabi, has access to the Holy books. The holy books form guidance for every Muslim, not just for Muslim scholars. Wahabists claim the right to interpret the Koran and the Sunnah independently of the prevailing opinions of Muslim scholars. Taqlid, or following the opinion blindly, is prohibited, according to them.

But how can the lay man understand the meaning of the Qur'an and Hadith without relying on Muslim scholars? To assist them, the Qur'an and the Hadith have been translated into local languages. Consequently, in practice, they reach the point that the call to return to the Qur'an and the Hadith has been reduced in the simplest terms: read the translations!

Reading the translation could certainly have some practical benefits. It does not require the extensive learning of Islam, which takes years and years. It also removes the roles of elite groups of Muslim scholars. No longer do Muslim scholars stand between their communities and the Holy books. Everyone now has access to the Qur'an and Hadith. In a way, this is how Wahabists 'modernise' their ideas of the Holy books. Understanding of the Qur'an and the Hadith is easy. However, is it true that reading the translation makes one fully understand the Qur'an and the Hadith?

The structure of the Qur'an makes it difficult to understand by reading the translations. The translation of the Qur'an to any other language is always limited to the understanding of the meanings which human translators have derived from their readings.220 The Qur'an is divided into 114 Chapters. It is not presented in narrative, explaining one topic in detail before moving to another topic. The presentation is rather sporadic: the Quran repeats certain verses and themes at times, shifts topics, and often relates narratives in summarised form. This is owing to the fact that the Quran was not revealed in one sitting, but was revealed in parts, over a span of 23 years. Many passages were revealed in response to specific events. The Quran does not mention genealogies, chronological events, or minute historical details, but rather uses events from both past and present to illustrate its central message.

Abdullah Saeed explains further:

In the case of verse Q.2:2 (dhalika al-kitabu la rayba fihi), those who are familiar with Arabic can understand the basic meaning of each word and the literal meaning of the sentence. This can be readily translated into English as, 'This is the book; there is no doubt about it', which is approximately the literal meaning. If one were dealing with this text in purely linguistic terms, this would be sufficient, but this does not tell us much about the overall purpose or meaning of the sentence. This text was revealed in a given context at a specific time as discourse for a particular purpose; therefore it has to be approached as discourse..$^{221}$

These are some of the things which a reader must look into, to understand a verse or Qur'anic concept. Unless he or she includes what went before and what follows a given verse or idea, and makes an effort at understanding the text as a unit, the meaning of the text he or she arrives at is likely to be unsatisfactory. In other words, reading the translation of the Qur'an will not give one the whole picture.

The same goes for the Hadith. Hadith too have an overall order and arrangement. A reader cannot properly understand and interpret a Hadith without considering the overall structure of Hadith. The second most important principle of understanding Hadith is that every Hadith has to be considered a part of the collective system of the narratives. A part, it is clear, has to be in

${ }^{220}$ Daoud Nassimi, 'Trsnaltions of Qur'anic verses with Injunctions: A Theme-based Comparative Review", in Mahmoud Ayoub (ed.), Contemporary Appraoches to the Qur'an and Sunnah (London: The International Institute of Islamic Thought, 2012), 118.

${ }^{221}$ Saeed, Interpreting the Qur'an, 107. 
accord with the overall structure of the whole. Every Hadith which is not in assonance with the overall structure of Hadith could be problematic.

I have discussed earlier that throughout history Muslim scholars have taken the science of interpretation of the Holy books very seriously. There is a difference between reading the Holy books for ritual purposes and reading for the issuance of a fatwa (legal advice). If anyone could interpret the Qur'an only by looking at the translation, it would be as if one could consume medicine by reading the label, without consultation with the doctor. The Qur'an and the Hadith are accessible for every Muslim, and therefore translations of the two sources are good, but one can't claim to know the full meaning of these sources without learning the Islamic knowledge (dirasah Islamiyah) in the first place.

In fact, Abdul Rahmaan ibn Mualaa al-Luwaihiq al-Mutairi explains how radical Muslims employ the same techniques which in a way remove the role of Muslims clergy in interpreting the Holy books, simply because very few Muslims have the ability to do so, this allegedly making the meaning of the Qur'an clear for everyone.222 In the Indonesian context, Jamhari Makruf outlines the use of Salafi (Wahabi) text in Islamic education, particularly in the area of theology (aqidah. - Creed. Belief) which leads to radicalisation, as in the case of the Ngruki Pesantren.223

However, my argument in this Paper goes further: It is as much the way in which the Salafi/wahabi jargon demanding a return to the Qur'an and Hadith is being implemented in its simplest terms - reading through the translation - which creates the problem of radicalisation. If my argument is right, we should focus not only on the textbooks, as pointed out by Makruf, but also on the way Islamic preachers on TV, radio, halaqah and majelis ta'lim, and most importantly, now in social media, teach people only by using a translation of the Qur'an and the Hadith without consulting the rich literature written by classic and modern Muslim scholars. In other words, the root of the problem is the way they rely on the translations and claim that by doing so they have already returned to the Qur'an and Hadith.

\section{Examples of Translation and Interpretation of the Qur'an and the Hadith}

In this section, I will provide three case studies on how reading the translations of the Qur'an and the Hadith is not only misleading, but also leads to radicalism. I will demonstrate how reading the Qur'anic verses and the sayings of the Prophet in the form of interpretations by Muslim scholars ('ulama) reveals different meanings to those gained by reading only translations (I have provided English translation; not Indonesian, as this Paper is in English).

\section{Q.S. al-Baqarah [2]: 120}

The translations are in the form of three different books:

Sahih International:224

And never will the Jews or the Christians approve of you until you follow their religion. Say, "Indeed, the guidance of Allah is the [only] guidance." If you were to follow their desires after what has come to you of knowledge, you would have against Allah no protector or helper.

\footnotetext{
${ }^{222}$ Abdul Rahman ibn Mualaa al-Luwaihiq al-Mutairi, Religious Extremism in the Lives of Contemporary Muslims (Denver: al-Basheer, 2001), 400-410.

${ }^{223}$ Jamhari Makruf, "Incubators for Extremists? Radicalism and Moderation in Indonesia's Islamic Education System", Centre for Indonesian Law, Islam and Society (CILIS) Policy Paper No 5, available at http://law.unimelb.edu.au/ data/assets/pdf file/0008/1547819/CILISPolicyPaper5Jamhari 3 wobleed2.pdf

${ }^{224}$ Sahih International translation of the Qur'an can be read in http://www.islamwb.com/books/quransaheeh-international-english-translation.pdf It is translated by an convert American woman, Umm Muhammad Assami, and published in Jeddah, Saudi Arabia.
} 
The Noble Qur'an:225

Never will the Jews nor the Christians be pleased with you (O Muhammad Peace be upon him) till you follow their religion. Say: "Verily, the Guidance of Allah (i.e. Islamic Monotheism) that is the (only) Guidance. And if you (O Muhammad Peace be upon him) were to follow their (Jews and Christians) desires after what you have received of Knowledge (i.e. the Qur'an), then you would have against Allah neither any Wali (protector or guardian) nor any helper.

Yusuf Ali: ${ }^{226}$

Never will the Jews or the Christians be satisfied with thee unless thou follow their form of religion. Say: "The Guidance of Allah, that is the (only) Guidance." Wert thou to follow their desires after the knowledge which hath reached thee, then wouldst thou find neither Protector nor helper against Allah.

Many Islamic preachers in Indonesia are using the verse above to illustrate how Jews and Christians hate Islam. ${ }^{227}$ This is a justification for them that inter-faith dialogue, collaboration, or even making friends with Jews and Christians, will lead to full conflict. They believe that gradually Jews and Christians try to convert Muslims to their religions. That is the understanding they gain from reading the translations of the verse above.

However, the meaning gained is different if one refers to the classic books of Tafsir which provide interpretations; and not translations. I refer to the three books: Tafsir Ibn Abbas, Tafsir al-Tabari, and Tafsir al-Baghawi, to explain the meaning of the verse. Tafsir Ibn Abbas has been attributed to the companion of the Prophet, Abdullah bin Abbas (618-697 AD), but many scholars are in doubt about who was the real author. The tafsir is considered to be a work which originated with Ibn Abbas and then was enlarged and modified by each of the students who transmitted the work, until eventually it reached a certain stage of growth, after which the versions were stabilised, this resulting in many different versions with the same title.228 Nevertheless, Muslim scholars still read and refer to Tafsir Ibn Abbas as an early book of Qur'anic exegesis. Tafsir al-Thabari was written by a great classic Muslim scholar, Abu Jarir alThabari (838-923 AD). He wrote his famous book of Qur'anic exegesis, Jami' al-Bayan fi Ta'wil al-Qur'an, in 26 volumes, widely recognised as one of the main books of tafsir. Abu Muhammad al-Husayn al-Farra' al-Baghawi (1041-1122 AD) was a renowned Persian Sunni Muslim scholar, best known for his major work Tafsir al-Baghawi (8 volumes). The three books referred to here are classic books, widely read and accepted in the Muslim world. Here is what the three books of tafsir say about QS al-Baqarah:120.

The first part of the verse (QS al-Baqarah:120) refers specifically to the Prophet Muhammad by using the second person pronouns "you" (wa lan tardha 'anka). Therefore it should not be seen as aimed at the Muslim community as a whole. For this target, one must refer to the asbab alnuzul (the historical context in which Quranic verses were revealed). Al-Baghawi explains that one version states that the verse was revealed when the Jews and Christians were asking for

225 The Noble Qur'an can be read in http://www.noblequran.com/translation/ It is translated by Muhammad Muhsin Khan and Muhammad Taqi-ud-Din al-Hilali. This English translation comes with a seal of approval from both the University of Medina and the Saudi Dar al-Ifta. It is also the most widely distributed version, of the Qur'an in the English language. However the translation has been criticised as part of Wahabi ideology.

226 Abdullah Yusuf Ali's 1934 translation of the Qur'an can be read in http://www.sacredtexts.com/isl/quran/index.htm His translation is one of the most widely known and used in the Englishspeaking world.

227 Bimo Nugroho, 'Writing the Dark Side: Publishing about Violence in Indonesia' in Charles A. Coppel (ed.) Violent conflict in Indonesia: analysis, representation, resolution (Oxon: Routlede, 2006).

${ }^{228}$ Andrew Rippin (1994), 'Tafsir Ibn 'Abbas and the Criteria for Dating Early Tafsir Texts', 18 Jerusalem Studies on Arabic and Islam, 38 
cease-fire, in return for which they would follow the Prophet Muhammad. ${ }^{229}$ However, he claims the verse was revealed to inform the Prophet that the Jews and Christians would not follow the Prophet's millat.

What is the meaning of millat here? Al-Thabari interpreted millat as religion. ${ }^{230}$ However, al-Baghawi interpreted millat as thariqah (the path). This means that, according to al-Baghawi, the verse informed the Prophet that Jews and Christians would not like him unless he followed their request to agree to a cease-fire. ${ }^{231}$

Al-Baghawi's interpretation of the word millat is interesting. The three translations from Shakir, Yusuf Ali and Sahih International clearly say millat is religion. If they adopted alBaghawi's interpretation, many Muslims would not use this verse as proof that Jews and Christians are trying to convert Muslims to become Jewish or Christian. Once again, millat as 'a path' here means having a cease-fire as proposed by the Jews and Christians; it has nothing to do with following the Jewish or Christian religions.

However, let us say for the sake of argument that we accept Thabari's interpretation, that millat means 'religion', Thabari explained that the meaning of the verse is that the Prophet Muhammad was asked to seek God's pleasure; and not to waste his time seeking to please the Jews and Christians. That's because the Jews and Christians would not please each other, and how could the Prophet himself please both of them? Therefore, the Prophet was told he should focus on his mission and not worry too much about the Jews and Christians. Accordingly, the verse is not about the how Jews and Christians would make Muslims follow their religions, but about the unrealistic expectations of the Prophet in wanting to please both Jews and Christians. ${ }^{232}$ This is what Thabari offered as his interpretation.

Ibn Abbas had a different version on the historical background of this verse. According to him, the Jews and Christians expected that the Prophet would pray facing towards Jerusalem, but when God ordered the Prophet to change the direction of prayer (qiblat) to the Ka'bah, the Jews and Christians were not happy. Therefore, Ibn Abbas specifically mentions that this verse referred to the Jews living in Madina and the Christians living in Najran, during the Prophet's time. Ibn Abbas did not extend the scope of the verse to all the Jews and Christians. ${ }^{233}$ If one follows Ibn Abbas' interpretation, then clearly the verse will not cover, for instance, the Crusades in the Middle Ages, nor the current Israeli- Palestinian conflict, which is what many Muslims preachers are trying to tell their audiences.

\section{Q.S. al-Fath: 29}

The English translations of the verse from three books are as follows:

Sahih International

Muhammad is the Messenger of Allah; and those with him are forceful against the disbelievers, merciful among themselves. You see them bowing and prostrating [in prayer], seeking bounty from Allah and [His] pleasure. Their mark is on their faces from the trace of prostration. That is their description in the Torah. And their description in the Gospel is as a plant which produces its offshoots and strengthens them so they grow firm and stand upon their stalks, delighting the sowers - so that Allah may enrage by them the disbelievers. Allah has promised those who believe and do righteous deeds among them forgiveness and a great reward.

\footnotetext{
${ }^{229}$ Abu Muhammad al-Husayn al-Farra' al-Baghawi, Tafsir al-Baghawi: Ma'alim al-Tanzil, Vol. 1, (Beirut: Dar Ibn Hazm, 2014), 161.

230 Abu Jarir al-Thabari, Jami' al-Bayan fi Ta'wil al-Qur'an, Vol. 2 (Beirut: Dar al-Fikr, 1998), 485.

231 Al-Baghawi, Tafsir al-Baghawi, 162.

232 Al-Thabari, op.cit., 486.

${ }^{233}$ Abdullah bin Abbas, Tanwir al-Miqbas min Tafsir Ibn Abbas, Vol 1 (Beirut: Dar al-Kutub Ilmiyyah, 1992), 17.
} 


\section{The Noble Qur'an:}

Muhammad is the Messenger of Allah, and those who are with him are severe against disbelievers, and merciful among themselves. You see them bowing and falling down prostrate (in prayer), seeking Bounty from Allah and (His) Good Pleasure. The mark of them (i.e. of their Faith) is on their faces (foreheads) from the traces of (their) prostration (during prayers). This is their description in the Taurat (Torah). But their description in the Injeel (Gospel) is like a (sown) seed which sends forth its shoot, then makes it strong, it then becomes thick, and it stands straight on its stem, delighting the sowers that He may enrage the disbelievers with them. Allah has promised those among them who believe (i.e. all those who follow Islamic Monotheism, the religion of Prophet Muhammad till the Day of Resurrection) and do righteous good deeds, forgiveness and a mighty reward (i.e. Paradise).

\section{Yusuf Ali:}

Muhammad is the messenger of Allah; and those who are with him are strong against Unbelievers, (but) compassionate amongst each other. Thou wilt see them bow and prostrate themselves (in prayer), seeking Grace from Allah and (His) Good Pleasure. On their faces are their marks, (being) the traces of their prostration. This is their similitude in the Taurat; and their similitude in the Gospel is: like a seed which sends forth its blade, then makes it strong; it then becomes thick, and it stands on its own stem, (filling) the sowers with wonder and delight. As a result, it fills the Unbelievers with rage at them. Allah has promised those among them who believe and do righteous deeds forgiveness, and a great Reward.

The verse above is used by many Islamic preachers to claim that the character of the true followers of the Prophet Muhammad are compassion amongst believers but strong against non-believers. The translation above, in practice, means that Muslims should help each other and at the same time be firm against the non-Muslims. This verse has been used as a weapon against moderate Muslims who make friends with non-Muslims. For instance, Abdurrahman Wahid (known as Gus Dur) was criticised heavily by Muslim preachers, including the Muslim politician Yusril Ihza Mahendra, based on the translation of the verse shown above. ${ }^{234}$ The late Gus Dur was the former General Chairman of the Nahdlatul Ulama (the largest Muslim organisation in Indonesia, whose membership is around 60 million), and also the forth President of Indonesia. He was widely known as a reformist, who was friends with Jews and Christians, and often was critical of his fellow, conservative, Muslims.

Let me offer three interpretations of the verse above from three books of Tafsir. This time I will refer to Tafsir Ibn Abbas, Tafsir Bahr al-'Ulum (al-Samarqandi), and Tafsir Ruh al-Ma'ani (alAlusi). I have spoken about Tafsir Ibn Abbas earlier. Tafsir Bahr al-'Ulum was written by Abu alLaith al-Samarqandi (898-983 AD), in 3 volumes. He was a Hanafi jurist and ascetic of Transoxania. Tafsir Ruh al-Ma'ani is written by the Iraqi scholar, Mahmud al-Alusi (1802-1854 AD), in 16 volumes. Al-Alusi was a respected scholar and served as a mufti in Baghdad. Let us see how they interpret Qs al-Fath:29, above.

Surah al-Fath was revealed in the context of the Hudaibiyah treaty. It was a pivotal treaty between Muhammad, representing the state of Medina, and the Quraysh tribe of Mecca in March 628. It helped to decrease tension between the two cities, affirmed a 10-year peace, and authorized Muhammad's followers to return the following year in a peaceful pilgrimage. Therefore, according to al- Alusi, one cannot understand the meaning of the last verse (29) in this surah unless one read it in the context of the Hudaibiyah incident. ${ }^{235}$

\footnotetext{
${ }^{234}$ Abdurrahman Wahid, 'Bersumber dari Pendangkalan' available at http://www.nu.or.id/post/read/74032/tulisan-gus-dur-bersumber-dari-pendangkalan

235 Mahmud al-Alusi, Ruh al-Ma'ani fi Tafsir al-Qur'an al-'Azim wa al-Sab' al-Mathani, Vol. 9 (Beirut: Dar Ihya al-Turath al-`Arabi, 2000), 127.
} 
In 628, Muhammad and a group of 1, 400 Muslims marched peacefully, unarmed, towards Mecca, in an attempt to perform the Umrah (pilgrimage). They were dressed as pilgrims, and brought sacrificial animals, hoping that the Quraish would honour the Arabian custom of allowing pilgrims to enter the city. However, Meccan emissaries wished to prevent the pilgrims' entry into Mecca. There was some tension, but both parties decided to reach agreement via the treaty. The treaty itself was considered by the Companions of the Prophet as controversial. In short, many of Muhammad's closest companions were dissatisfied with the result, as they thought that they had the power to use force, and the text of the treaty was not in favour of Muslims generally, owing to the fact that the Prophet Muhammad took a very much compromised position towards the Quraish Meccans. ${ }^{236}$

Therefore, according to al-Alusi, in his Tafsir Ruh al-Ma'ani, the verse was revealed in the conflict and tension post-Hudaibiyah. ${ }^{237}$ Some of Muhammad's companions were influenced by propaganda spread by the hypocrites amongst them, as revealed in the earlier verses of the Qur'an in Surah (QS) al-Fath. Some even questioned whether the Prophet's dream of entering Mecca was authentic. Some went further, questioning whether the Prophet was the real Messenger of Allah. Internally, the Hudaibiyah incident threatened the unity of the Muslim community. Then God revealed the last verse of this Surah, verse 29, as can be read above.

The first point al-Alusi makes is really important. The verse above was not handed down during normal daily life. Therefore, one could question whether it would be appropriate to apply the above verse - compassionate amongst the believers but strong against the non-believersin normal situations. One could read the meaning of the verse to be that Muslims should not be firm against each other, they have to be compassionate within their community, and that such firmness should be directed towards the enemy, not towards fellow Muslims.

Tafsir Ibn Abbas was of the view that the above verse was directed specifically at those who were present at the Hudaibiyah incident; not that it be extended to all Muslims in all situations. Therefore, Tafsir Ibn Abbas proposes the reading of the meaning of the verse as, Muhammad is the messenger of Allah (unlike the testimony of Suhail bin Amr [who represented the Meccan]); and those who are (this specifically refers to the companion Abu Bakar, the first who believed in him and called the disbelievers with him to the religion of Allah) with him (Muhammad) are strong against Unbelievers (this refers to 'Umar Ibn al-Khattab who was tough with the enemies of Allah, strong in the religion of Allah and a defender of Allah's Messenger) and compassionate amongst each other (this refers to 'Uthman Ibn 'Affan who was very dutiful and merciful towards Muslims, and spent much of his money on them) Thou (Oh Muhammad) seest them bowing in prayer and falling prostrate in worship (this refers to 'Ali Ibn Abi Talib who abundantly bowed and prostrated in prayer), seeking bounty reward from Allah and His acceptance (through jihad; this refers to Talhah and al-Zubayr who were very hard on, and tough with, disbelievers. The mark of them is on their foreheads from (the sign of their staying awake is on their faces from) the traces of prostration (from repeated prostration at night; this refers to Salman al-Farisi, Bilal, Suhayb and their fellow believers). Such is their likeness (their description) in the Torah and their likeness in the Gospel is like sown corn (this is the Prophet Muhammad) that Allah sendeth forth its shoot (i.e. Abu Bakr, the first to believe in him and the first to face the enemies of Allah) and strengtheneth it (and assists him; this is 'Umar who assisted the Prophet with his sword against the enemies of Allah and riseth firm (he became strong with the wealth of 'Uthman which he used in jihad in the way of Allah upon its stalk (and spread his message among Quraysh through 'Ali Ibn Abi Talib), delighting the sowers (the Prophet was pleased with Talhah and al-Zubayr) that He may enrage the disbelievers with the sight of them (by means of Talhah and al-Zubayr). It is also said that this verse was revealed in

236 Safi-ur-Rahman Al-Mubarakpuri, The Sealed Nectar: Biography of the Noble Prophet (Riyad: Darussalam, 2002), 398-410.

237 Al-Alusi, Ruh al-Ma'ani, 129. 
praise of those who took part in the swearing of allegiance at Ridwan ${ }^{238}$ and the sincere, obedient prophetic Companions in general. Allah hath promised, unto such of them as believe (in Muhammad and the Qur'an) and do good works (and do acts of obedience in private between themselves and their Lord), forgiveness (of their sins in this world and in the Hereafter and immense reward (and abundant reward in the Garden). ${ }^{239}$

It is worth considering that al-Samarqandi in his Bahr al-'Ulum followed the Tafsir Ibn Abbas approach above; that the verse specifically referred to those who were present at the Hudaibiyah. The differences between Tafsir Ibn Abbas and Tafsir Bahr al-'Ulum are on listing the names, according to the specific phrases in the verse. For instance, 'seeking bounty reward from Allah and His acceptance': Ibn Abbas refers this phrase to Talhah and al-Zubayr, whereas al-Samarqandi refers to al-Zubayr and Abdurrahman bin Awf.240

Tafsir al-Alusi mentions that the majority of Muslim scholars were of the view that the characteristics of the Muslims in this verse are not limited to the great Companions above, who were present at the Hudaibiyah, but to all of the Prophet's companions. ${ }^{241}$ Even if we accept the majority opinion, the phrase assyidda'u 'alal kuffar (strong against unbelievers) was sent down when the Prophet took a very much compromised position in the Hudaibiyah treaty. At that time, the Prophet Muhammad returned to Madinah and did not use force to enter Mecca. This indicates that the word 'strong' or 'firm', as a translation of assyidda'u, does not mean using force nor waging war.

The word means negotiating and accepting the peace treaty, while having a firm believe not to surrender to the non-believers. This could be seen as part of the Prophet's and his Companions' application of assyidda'u 'alal kuffar. This relates to QS al-Mumtahanah: 8-9:

Allah does not forbid you to deal justly and kindly with those who fought not against you on account of religion and did not drive you out of your homes. Verily, Allah loves those who deal with equity. It is only as regards those who fought against you on account of religion, and have driven you out of your homes, and helped to drive you out, that Allah forbids you to befriend them. And whosoever will befriend them, then such are the Zalimun (wrong-doers those who disobey Allah).

\section{Fight non-Muslims until they accept Islam (Hadith of the Prophet Muhammad)}

The third case study is the statement from the Hadith:

Narrated by Ibn 'Umar

Allah's Apostle said: "I have been ordered (by Allah) to fight against the people until they testify that none has the right to be worshipped but Allah and that Muhammad is Allah's Apostle, and offer the prayers perfectly and give the obligatory charity, so if they perform that, then they save their lives and property from me except for Islamic laws and then their reckoning (accounts) will be done by Allah."

The above Hadith is authentic statement as it was recorded in Shahih Bukhari, Shahih Muslim and other main books of Hadith. ${ }^{242}$ Many Muslim preachers have used the hadith above to explain the mission of the Prophet to spread Islam by any means. But what of 'Let there be no compulsion in religion' (QS al-Baqarah:256)? Can it be true that the meaning of the Hadith above is that the Prophet would force people to embrace Islam?

\footnotetext{
238 It was a pledge that was sworn to the prophet Muhammad by his companions prior to the Treaty of Hudaybiyyah. The pledge, sworn under a tree, was to avenge the rumored death of Uthman ibn Affan. ${ }^{239}$ Abdullah bin Abbas, Tanwir al-Miqbas min Tafsir ibn Abbas, Vol. 1 (Beirut: Dar al-Kutub Ilmiyyah, 1992), 434.

240 Abu al-Layth al-Samarqandi, Bahr al-'Ulum, Vol. 3 (Bairut: Dar al-Fikr, 2005), 320.

241 Al-Alusi, Ruh al-Ma'ani, 39.

242 Abu 'Abd Allah Muhammad bin Isma'il al-Bukhari, Sahih Bukhari (Dar al-Qalam, 1987).
} 
The reading of the Sharh (explanation) of the Hadith reveals a different meaning than the translation above. This is another piece of evidence of the danger of returning to the Qur'an and Hadith based only on translations, without understanding the context of such statements and the explanations by Muslim scholars about the texts. Preaching the Hadith above, by merely translating it, can lead to extremism.

Here I am using the explanation of Ibn Hajar al-Asqalani (1372-1449 AD) in his book Fath al-Bari. Ibn Hajar was a well-respected Shafi'i Sunni scholar and appointed as the Egyptian chief judge. His book Fath al-Bari is considered as the most authoritative commentary on Hadith compiled in Shahih Bukhari book. ${ }^{243}$ It took him 25 years to complete this commentary book.

Ibn Hajar explains that the Hadith above is in the context of Allah's saying, "If they turn in repentance" (QS al-Taubah: 5). This verse talks about having a war with the polytheists who attacked Muslims at the end of peace treaties. The phrase in the Hadith above, "I have been ordered (by Allah) to fight against the people". It is not for all people, but for a specific category, under specific circumstances (al-'am alladzi urida bihi al-khas). If we compare this with other narrations, the word 'people' has been replaced with the word 'Polytheist', as mentioned in Sunan al-Nasa'i, Hadith Number 3903 ("umirtu an uqaatila al-mushrikin"). Therefore, people of the book (Christian and Jews) are excluded.244

The verse then continues "but if they turn in repentance", Bukhari used the hadith as an explanation of this Qur'anic phrase, because what is meant by 'repentance' in the verse is the return from disbelief to Islamic tawhid (monotheism). This meaning was explained with the statement of the hadith "until they testify that none has the right to be worshipped but Allah and that Muhammad is Allah's Apostle". Another correlation between the verse and the Hadith is that the refrainment mentioned in the verse (if they turn in repentance... let them go on their way) and the protection in the hadith (if they do that, their lives and property are protected from me) share the same meaning.

This necessitates that once the testimony of faith occurs, prayer is established, and zakat is given, the person's blood is secure (i.e. his life) even if he rejects the remaining orders. Prayer and Zakat cannot be separated - these are the minimum requirement of faith. However, there is a difference between the two (i.e. salat and zakat) in the fact that zakat can be taken using force from a person who attempts to abstain from paying it, as opposed to the salat (wherein force is not used to establish it). The proof (for this opinion) is in the actions of Abu Bakr As-Siddiq, the first Caliph, who fought those who refused to pay zakat (after the death of the Prophet Muhammad.) Umar bin Khattab reminded the Caliph that their blood is secured and protected because they believe in tawhid and pray salat. Their transgression was only in refusing to pay zakat. The Caliph disagreed. According to him, the ensuring of blood being secured and protected is by fulfilling all conditions, including paying zakat. With this justification, the Caliph fought those who did not want to pay zakat based on the above Hadith.

Ibn Hajar quoted the opinion of Ibn Daqiq al-Eid, another well-known Shafi'i scholar, that the permissibility of using force against transgressors does not necessarily state the permissibility of killing them (by way of corporal punishment), because combat comprises struggle and fighting by both sides, unlike the outright killing (of a person). Al-Baihaqi reported that Imam al-Shafi'i said, "Combat (al-Qital) is not the same as killing (al-Qatl), and the permissibility of fighting may apply at times, without the permissibility of the killing of a person." Ibn Haiar highlighted that there was no single source indicating that Abu Bakar killed those who refused to pay zakat. Abu Bakar merely used military force to make them pay zakat, and they did.

${ }^{243}$ See Abdul Hakim Murad, 'Fath al-Bari: Commentary on Sahih al-Bukhari' available at http://www.sunnah.org/history/Scholars/fath al bari.htm

${ }^{244}$ Ibn Hajar, Fath al-Bari bi Sharh Sahih al-Bukhari, Vol 1 (Beirut: al-Risalah al-'Alamiyyah, 2013), 75-77. 
The last phrase from the above Hadith: "their reckoning (accounts) will be done by Allah" means that Allah is the One who will judge their secret affairs. Ibn Hajar believes that people of innovations (bid'ah) are not disbelievers as long as they declare the tawhid of Allah, and accept the Shari'a as revelation. The repentance of one who returns (to Islam) from disbelief is accepted, without attempting to differentiate between their outward and inward disbelief (or intentions).

It is interesting that Ibn Hajar makes an argument, using the above hadith, that Muslims should not fight those who conduct innovations (bid'ah) in the religion. Salafi/wahabi groups are strongly against people of bid'ah. Sheikh Uthaimin explains about bid'ah as "Worshipping Allah in ways that Allah has not prescribed, or, if you wish, you may say worshipping Allah in ways that are not those of the Prophet or his rightly guided successors (al-Khulafa alRashidun)."245 It can be stated safely that everyone who worships Allah in a manner that Allah has not prescribed or in a manner that is not in accord with the practice and example of the Prophet or his rightly-guided successors, is an innovator. With regard to ordinary matters of habit and custom, these are not called bid'ah (innovation) in Islam.

Innovation outside pure ritual matters is accepted and even encouraged in Islam, such as in building universities, travelling by airplane, and watching television are considered products of innovation. However, morning prayer must be performed in two raka'ah (unit). No Muslims are allowed to make innovation regarding this prayer by reducing nor adding raka'ah. How can one draw a line between the expression and the implementation of ritual, and the core ritual itself. Is celebrating the birth of the Prophet part of the expression or the core ritual? Is it permitted or not? Salafi groups generalise that all expression and implementation of the ritual is part of the core element and innovation is prohibited.

Other Muslims groups are more flexible, accommodating local culture as part of the expression in implementing ritual, and say innovation -as long as it does not change the core element of the ritual - should be allowed. Ibn Hajar argues in this context, that one cannot fight or force people who are claimed to be conducting bid'ah in religion, as the last phrase from the above hadith states: "their reckoning (accounts) will be done by Allah", meaning that Allah is the one who will judge them in the hereafter as to whether their actions are right or wrong; not humans. Such explanation is against the takfiri movement (which accuses Muslims of differing views of committing apostasy and states that therefore their blood is halal).

The verse of the Qur'an in al-Taubah: 5 "slay the idolaters/polytheists wherever you find them" and the hadith that we are discussing "I have been ordered (by Allah) to fight against the people" were not handed down during normal daily life. They were in the context of war. In the normal and peace situation, one should refer to "And had your Lord willed, those on earth would have believed - all of them entirely. Then, [O Muhammad], would you compel the people in order that they become believers?" (QS Yunus:99) and "Let there be no compulsion in religion" (QS al-Baqarah:256).

\section{E. Concluding Remarks}

The Paper is an attempt to illustrate that the call to return to the Qur'an and Hadith through social media is problematic, if not misleading. In practice, Muslim preachers in halaqah, schools, and majelis ta'lim teach Islam using only translations of the Qur'an and Hadith. They claim this is sufficient. I argue that this is not sufficient. Relying solely on translation can be dangerous as it does not inform readers of the context and the rich interpretations, written by classic and modern scholars. Consequently, this can lead to radicalisation, as I have demonstrated in the three case studies above.

245 Muhammad Salih bin Utsaimin, Majmu' Fatawa wa Rasail, Vol. 2, (Dar al-Wathan li al-Nashr, 1413 H), 292. 
Reading translations of the Qur'an and Hadith is only the first step to understanding Islamic teaching. I would encourage Muslim preachers not to stop there, but to continue explaining the meaning of the Qur'anic verses and the statements of the Prophet using the most authoritative commentaries recognised throughout the history of Islam. This begs the question about the qualification of Muslim preachers; whether those who appears frequently in the media possess the required qualifications to access and analyse Islamic literature which is written mostly in classic Arabic. ${ }^{246}$ The problem with radicalisation is ignorance. I have just demonstrated the root of the problem in understanding the Qur'an and Hadith among Indonesian Muslims.

Islamic teaching today may be based on the original two primary sources (the Qur'an and Hadith) but the majority of rules which apply were developed over 15 centuries of juristic interpretation, scholarly work and occasional pronouncements by authorities. Therefore, some rules and principles are based on facts and circumstances which existed many centuries ago. In this sense, contemporary Muslim scholars must find a way to determine which principles should be maintained, and which ones should be adjusted in response to social changes. Islamic principles support the flexibility and adjustability of pronouncements to the requirements of time. This can be done through the interpretation -a serious matter in Islamic tradition - and not simply by returning to the translation of the Qur'an and Hadith.

\section{Bibliography}

"Abdullah Yusuf Ali's 1934 translation of the Qur'an", in http://www.sacredtexts.com/isl/quran/index.htm His translation is one of the most widely known and used in the English- speaking world.

Abbas, Abdullah bin. Tanwir al-Miqbas min Tafsir ibn Abbas, Vol 1. Beirut: Dar al-Kutub Ilmiyyah, 1992.

Alusi (al-), Mahmud. Ruh al-Ma'ani fi Tafsir al-Qur'an al-'Azim wa al-Sab' al-Mathani, Vol. 9. Beirut: Dar Ihya al-Turath al-Arabi, 2000.

Alwani (al-), Taha Jabir. The Ethics of Disagreement in Islam. Herndon, Virginia: The Internasional Institute of Islamic Thought, 2011.

Baghawi (al-), Abu Muhammad al-Husayn al-Farra'. Tafsir al-Baghawi: Ma'alim al-Tanzil, Vol 1. Beirut: Dar Ibn Hazm, 2014.

Brown, Jonathan AC. Misquoting Muhammad: The Challenge and Choices of Interpreting the Prophet's Legacy. London: Oneword Publications, 2014.

Bukhari (al-), Abu 'Abd Allah Muhammad bin Isma'il. Sahih Bukhari. Dar al-Qalam, 1987.

Calder, Norman. Studies in Early Muslim Jurisprudence. Oxford: Clarendon Press, 1993.

Darimi (al-), Abu Muhammad. Sunan al-Darimi. Beirut: Dar al-Kitab al-'Arabi, 1997.

\footnotetext{
${ }^{246}$ Minister of Religious Affairs, Lukman Hakim Saifuddin, has recently suggested that all the Muslim preachers should be certified by the Government, just like lectures in the University. Therefore, those who do not have sufficient knowledge would be prevented to deliver the sermon in the mosques and media. But he received hars criticism from many Islamic organisations and Muslim preachers as the way they see it this is an attempt from the government to control and intervene Muslim affairs. Read his interview in Tempo Magazine here 'Minister Lukman Hakim Saifuddin: clerics must be certified', available at https://en.tempo.co/read/news/2017/01/24/241839242/Minister-Lukman-Hakim-Saifuddin-clericsmust-be-certified
} 
Vol. 1 No. 1, 2019

Dawalibi (al-), Muhammad Ma'ruf. Al-Madkhal ila 'Ilm al-Usul al- Fiqh. Damascus, Matba'ah Jami'ah Damshiq, 1959.

Gleave, Robert. Islam and Literalism: Literal Meaning and Interpretation in Islamic Legal Theory. Edinburgh: Edinburgh University Press, 2012.

Hajar, Ibn. Fath al-Bari bi Sharh Sahih al-Bukhari, Vol. 1. Beirut: al-Risalah al-'Alamiyyah, 2013.

Hallaq, Wael B. An Introduction to Islamic Law. Cambridge University Press, 2009.

Hasan, Ahmad. The Early Development of Islamic Jurisprudence. Islamabad: Islamic Research Institute, 1970.

Kamali, M. Hashim. A Textbook of Hadith Studies. Markfield, UK: The Islamic Foundation, 2009.

Kamali, M. Hashim. Principles of Islamic Jurisprudence. Cambridge: Cambridge Islamic Texts Society, 1991.

Madkur, Muhammad Salam. Manahij al-Ijtihad fi al-Islam. Kuwait: Matba'ah al-Ashriyah, 1977.

Makruf, Jamhari. "Incubators for Extremists? Radicalism and Moderation in Indonesia's Islamic Education System". Centre for Indonesian Law, Islam and Society (CILIS) Policy Paper No. 5, available at http://law.unimelb.edu.au/ data/assets/pdf_file/0008/1547819/CILISPolicyPaper5- Jamhari_3_wobleed2.pdf

Masud, Muhammad Khalid. Shatibi's Philosophy of Islamic Law. Pakistan, Islamic Research Institute, 1995.

"Minister Lukman Hakim Saifuddin: clerics must be certified", in https://en.tempo.co/read/news/2017/01/24/241839242/Minister-Lukman-HakimSaifuddin- clerics-must-be-certified

Mubarakpuri (al-), Safi-ur-Rahman. The Sealed Nectar: Biography of the Noble Prophet. Riyad: Darussalam, 2002.

Murad, Abdul Hakim. "Fath al-Bari: Commentary on Sahih al-Bukhari", in http://www.sunnah.org/history/Scholars/fath al bari.htm

Mutairi (al-), Abdul Rahmaan ibn Mualaa al-Luwaihiq. Religious Extremism in the Lives of Contemprary Muslims. Denver, al-Basheer, 2001.

Nassimi, Daoud. 'Translations of Qur'anic verses with Injunctions: A Theme-based Comparative Review", in Ayoub, Mahmoud (ed.), Contemporary Approaches to the Qur'an and Sunnah. London: The International Institute of Islamic Thought, 2012.

Nugroho, Bimo. "Writing the Dark Side: Publishing about Violence in Indonesia", in Charles A. Coppel (ed.) Violent conflict in Indonesia: analysis, representation, resolution. Oxon: Routlede, 2006.

Quraishi, Asifa. "Interpreting the Qur'an and the Constitution: Similarities in the Use of Text, Tradition, and Reason in Islamic and American Jurisprudence", (2006), 28 Cardozo Law Review, 67.

Rippin, Andrew. 'Tafsir Ibn 'Abbas and the Criteria for Dating Early Tafsir Texts”, 18 Jerusalem Studies on Arabic and Islam, 1994.

Saeed, Abdullah. Interpreting the Qur'an: Towards a Contemporary Approach. New York: Routledge, 2006.

"Sahih International translation of the Qur'an", in http://www.islamwb.com/books/quransaheeh-international-english-translation.pdf It is translated by an convert American woman, Umm Muhammad Assami, and published in Jeddah, Saudi Arabia. 
Samarqandi (al-), Abu al-Laith. Bahr al-'Ulum, Vol. 3. Bairut: Dar al-Fikr, 2005.

Sulaiman, Abu Dawud. Sunan Abi Dawud. Beirut: al-Maktabah al-'Ashriyah, 1952.

Tabari (al-), Abu Jarir. Jami' al-Bayan fi Ta'wil al-Qur'an. Vol. 2. Beirut: Dar al-Fikr, 1998.

“The Noble Qur'an", in http://www.noblequran.com/translation/ It is translated by Muhammad Muhsin Khan and Muhammad Taqi-ud-Din al-Hilali.

Tirmidhi (al-), Sunan al-Tirmidhi. Beirut: Dar al-Fikr, 1963.

Utsaimin, Muhammad Salih bin. Majmu' Fatawa wa Rasail, Vol. 2. Dar al-Wathan li al-Nashr, 1413 $\mathrm{H}$.

Wahid, Abdurrahman. "Bersumber dari Pendangkalan", in http://www.nu.or.id/post/read/74032/tulisan-gus-dur-bersumber-dari-pendangkalan

Zarkashi (al-), Badr al-Din. Bahr al-Muhith fi Usul al-Fiqh, Vol. 1. Beirut: Dar al-Kutub al-Ilmiyah, 2007. 